\title{
The phenomenon of synaptic vesicle clustering as the prefusion state in the model system of exocytosis
}

\author{
Vitaliy P. Gumenyuk ${ }^{1}$, Alexander Yu. Chunikhin ${ }^{2}$, Nina H. Himmelreich ${ }^{1}$ and Irene O. Trikash ${ }^{1}$ \\ ${ }^{1}$ Department of Neurochemistry, Palladin Institute of Biochemistry, National Academy of Sciences of Ukraine, 9 Leontovich \\ str., 01601, Kiev, Ukraine \\ ${ }^{2}$ Laboratory of Optical Methods Investigations, Palladin Institute of Biochemistry, National Academy of Sciences of Ukraine, \\ 9 Leontovich str., 01601, Kiev, Ukraine
}

\begin{abstract}
Our findings concern to the synaptic vesicle interactions that were reconstructed in the cellfree system and are thought to represent the different states of exocytosis pathway. The combination of different technical approaches allowed to study the features of aggregation and calcium-dependent homotypic fusion of synaptic vesicles. Electron microscopy observations of synaptic vesicle fraction purified from the rat brain showed the appearance of large particles formed by aggregated synaptic vesicles in the presence of the nerve terminal cytosolic proteins only. This data were confirmed by dynamic light scattering measurements indicating an importance of the cytosolic proteins for the formation of synaptic vesicle clusters. The scanning confocal microscopy and imaginative exploitation of fluorescence probe R18 allowed to distinguish the process of synaptic vesicle clustering from the synaptic vesicle fusion. The stimulating effect of antiepileptic drug ethosuximide and sodium valproate on the formation of synaptic vesicle aggregates has been revealed. Experiments with the removal of cholesterol showed that such modification of synaptic vesicle membranes did not change the ability of synaptic vesicles to form the clusters, while reducing their $\mathrm{Ca}^{2+}$-triggered membrane fusion. Thus, our data have shown that aggregated state of synaptic vesicles represent an intermediate stage of the fusion pathway, where aggregation of synaptic vesicles is preceded by $\mathrm{Ca}^{2+}$-dependent membrane fusion.
\end{abstract}

Key words: Synaptic vesicle aggregation - Membrane fusion - Cell-free system - Cholesterol - Antiepileptic drugs

\section{Introduction}

Docking is considered to be the necessary intermediate step that occurs before the synaptic vesicles gained the competence to fuse and release the neurotransmitters. Recently, only a fraction of docked synaptic vesicles was shown to fuse with plasmalemma upon $\mathrm{Ca}^{2+}$-influx (Wadel et al. 2007). The electron tomography studies revealed that synaptic vesicles are linked to each other and organized in clusters or tight aggregations (Fernandez-Busnadiego et al. 2010). In order to complete this, the synaptic vesicles have a distinct set of

Correspondence to: Irene O. Trikash, Department of Neurochemistry, Palladin Institute of Biochemistry, National Academy of Sciences of Ukraine, 9 Leontovich str., 01601, Kiev, Ukraine E-mail: trikash@biochem.kiev.ua proteins comprised including the vesicular SNARE protein synaptobrevin/VAMP-2, synaptophysin and the calciumand phospholipid-binding protein synaptotagmin 1 (Sudhof 2004). It was suggested that MUNC18-1 that bind to the neuronal SNARE-complex (Dulubova et al. 2007) by forming a complex with syntaxin, takes place in neurotransmitter release through the mediation of docking and fusion of synaptic vesicles with presynaptic membranes (de Wit et al. 2006; Verhage and Sorensen 2008). Moreover, there has been a model proposed where several presynaptic proteins selectively localized in synaptic vesicle clusters form a complex proteinaceous net that restrains their mobility (Shupliakov 2009). The majority of vesicles in the nerve terminal support neurotransmitter release indirectly being cross-linked to each other by acting as a molecular buffer. Disrupting the clusters by application of black widow spider venom resulted 
in the diffusion of numerous soluble proteins into the axons (Denker et al. 2011).

Strong and prolonged stimulation of synapses may lead to copious exocytosis. It might bring about compound exocytosis where vesicles fuse to each other before the fusion with plasma membrane (Pickett and Edwardson 2006). The homotypic type of calcium-induced fusion of synaptic vesicles with each other was exposed in vitro to model the last step of exocytosis (Trikash et al. 2004). The simplified model consisting of homotypic membranes of isolated synaptic vesicles obtained from the synaptosomal fraction of rat brain tissue was studied. It was shown that synaptic vesicle membrane fusion develops in the presence of synaptosomal cytoplasmic proteins and $10^{-7}-10^{-5} \mathrm{M} \mathrm{Ca}^{2+}$ ions. This conclusion was made based on changes in the intensity of fluorescence of a probe R18. Calcium ions were found to be the most effective activators of the membrane fusion when the effects of bivalent cations, $\mathrm{Ca}^{2+}, \mathrm{Sr}^{2+}$, and $\mathrm{Ba}^{2+}$, were compared. These findings allow us to believe that there are factors in the system containing synaptic vesicles and synaptosomal cytosolic proteins, which initiate fusion of the membranes under the influence of $\mathrm{Ca}^{2+}$.

Our studies in cell-free system have shown that the process of synaptic vesicle interactions in the medium of synaptosomal cytosolic proteins can be divided into two consecutive stages - docking and $\mathrm{Ca}^{2+}$ triggering membrane fusion (Trikash et al. 2008). The testing and characterization of these exocytotic steps was demonstrated by using two different approaches in vitro. The interaction of synaptic vesicles was determined by the changing of particles size in suspensions by the method of dynamic light scattering. Fluorescence assay is represented for studying the process of synaptic vesicle membrane fusion.

It is known that the cholesterol greatly enriched in membranes of synapses and synaptic vesicles and is up to $40 \%$ of the total lipid (Benfenati et al. 1989). Moreover, some synaptic fusion proteins bind directly to cholesterol (Epand 2006). We expect that modulating the cholesterol levels in synaptic vesicles by methyl- $\beta$-cyclodextrin (MCD) would affect the course of the exocytosis stages in model experiments because the cholesterol deprivation by MCD was shown to disrupt cholesterol-enriched functional microdomains and to inhibit exocytosis in various cells (Pike and Miller 1998; Belmonte et al. 2005; Churchward et al. 2005; Chintagari et al. 2006; Brunham et al. 2008; Zhang et al. 2009).

Recently, we have shown the significant stimulatory action of anticonvulsive agents (ethosuximide and sodium valproate) on initiated merger synaptic vesicle membranes with each other (homotypic fusion) and synaptosomal plasma membranes (heterotypic fusion) (Trikash et al. 2003; Gumenyuk et al. 2009).

In this manuscript, we focused on the features of the synaptic vesicle aggregation where close contact of their membranes do not result in fusion. This cell-free approach provides some possibilities to study the influence of antiepileptic drugs and MCD on the steps of exocytosis. Thus, our studies have yielded new insights for understanding of the synaptic vesicle clustering features as a prefusion stage before calcium-induced membrane fusion.

\section{Materials and Methods}

The studies were performed according to the guidelines of National Academy of Sciences of Ukraine in accordance with the European Community Council Directive of 24 November 1986 (86/609/EEC). The paper was submitted to the Institutional Animal Care and Use Committee (IACUC) and had institutional approval in according to the report No. 1/7-243 from 15.05.2012. All animals had access to food and water ad libitum and were kept in a 12-h light cycle. Every effort was made to minimize suffering and limit the number of animals used.

\section{Materials}

Ethosuximide (3-ethyl-3-methylpyrrolidine-2,5-dione), sodium valproate (2-propylpentanoic acid, sodium salt), methyl- $\beta$-cyclodextrin were purchased from Sigma, USA. R18 was purchased from Molecular Probe (Eugene, OR, USA); $\mathrm{C}_{12} \mathrm{E}_{8}$ (octaethyleneglycol-dodecyl ether) was purchased from Calbiochem, USA. All other chemicals were of analytical grade.

\section{Synaptosome preparation}

The Wistar rats (150-200 g body weight) were killed by decapitation, the brains were rapidly removed and kept on ice. Rat brains were weighed, cut into pieces, transferred to ice-cold $0.32 \mathrm{M}$ sucrose, $10 \mathrm{mM}$ Tris- $\mathrm{HCl}, \mathrm{pH} 7.5(9 \mathrm{ml} / \mathrm{g}$ of brain tissue) and gently homogenized using a glass homogenizer with a teflon plunger $(0.25 \mathrm{~mm}$ clearance). All manipulations were performed at $0^{\circ} \mathrm{C}$. Synaptosomes were prepared by differential centrifugation of rat brain homogenate. The homogenate was centrifuged at $1,500 \times g$ for $10 \mathrm{~min}$ and the supernatant was removed and centrifuged at $12,000 \times g$ for $20 \mathrm{~min}$. The resultant pellet was the fraction of crude synaptosomes.

\section{Isolation of synaptic vesicles and cytosolic fraction of synaptosomes}

Crude synaptosomes were lysed by rapid resuspension in $1 \mathrm{mM}$ EGTA, $10 \mathrm{mM}$ Tris-HCl, pH 8.1 (3 ml/g of brain tissue) and incubated at $4^{\circ} \mathrm{C}$ for $60 \mathrm{~min}$. The preparation was centrifuged at $20,000 \times g$ for $30 \mathrm{~min}$. The pellet $\left(\mathrm{M}_{1}\right)$ was 
used to separate the plasma membranes of synaptosomes (de Lores Arnaiz et al. 1967). The supernatant was centrifuged at 55,000 $\times g$ for $60 \mathrm{~min}$. The supernatant was centrifuged again at $130,000 \times g, 4^{\circ} \mathrm{C}$ for 60 min to obtain the synaptic vesicle fraction (pellet) and the cytosolic fraction of synaptosomes (supernatant) (de Lorenzo and Freedman 1978). The synaptic vesicle pellet was suspended in $10 \mathrm{mM}$ Tris$\mathrm{HCl}(\mathrm{pH}$ 7.5). The composition of the vesicle fraction was controlled by plasma membranes marker $\left(\mathrm{Na}^{+} / \mathrm{K}^{+}\right.$-ATPase). No plasma membranes contamination was present in the purified synaptic vesicle preparation since $\mathrm{Na}^{+} / \mathrm{K}^{+}$-ATPase could not be detected after purification.

\section{Dynamic light scattering method for monitoring of synaptic vesicle aggregation}

The hydrodynamic diameter of the particles in synaptic vesicle suspension was measured by photon correlation spectroscopy using a Malvern Zetasizer-3 spectrometer (Malvern Instruments, Worcestershire, U.K.). The light source was a 25 $\mathrm{mW}$ He-Ne laser $(\lambda=632.8 \mathrm{~nm})$ and the scattered light was measured under $90^{\circ}$ angle.

Fifty microliters of vesicle suspension ( $50 \mu \mathrm{g}$ of proteins) were injected into cuvette containing $950 \mathrm{ml}$ of the buffer solution (1 mM EGTA, 10 mM Tris-HCl, pH 8.1) or synaptosomal cytosolic fraction (protein concentration $1 \mathrm{mg} / \mathrm{ml}$, $1 \mathrm{mM}$ EGTA, $10 \mathrm{mM}$ Tris- $\mathrm{HCl}, \mathrm{pH}$ 8.1). The measurements were performed at a room temperature.

The scattered intensity is time-dependent when observed on a microsecond timescale due to the Brownian motion of the nanoparticles. On this timescale, intensity fluctuations reflect the rate of diffusion of the particles. These fluctuations are captured using the method of autocorrelation (Merkus 2009; McNeil 2011). From the decay of the correlation function, the rate of diffusion is calculated:

$$
\Gamma=q^{2} D
$$

where $\Gamma$ is the exponential decay rate and $q$ is the modulus of the scattering vector.

The Stokes-Einstein equation can then be used to relate $D$ to the hydrodynamic diameter $\left(d_{\mathrm{H}}\right)$ of the particle, taking into account the viscosity of the sample solution and the temperature at which the measurement is performed.

$$
d_{\mathrm{H}}=k T / 3 \pi \eta D
$$

where $k$ is the Boltzmann constant, $T$ is the absolute temperature, and $\eta$ is the absolute zero-shear viscosity of the medium. The quantity $d_{\mathrm{H}}$ is the diameter of an equivalent rigid sphere that diffuses at the same rate as the analyte.

Data were analyzed with the Contin algorithm (Malvern Instruments), which calculates the Z-average size and polydis- persity. The transforms of the photon-correlation spectroscopy (PCS) intensity distribution to volume distributions is obtained using the provided software by Malvern Instruments.

\section{Electron microscopy}

The synaptic vesicle fraction in the medium containing $10 \mathrm{mM}$ Tris- $\mathrm{HCl}$ ( $\mathrm{pH}$ 7.5) was purified by filtering through glass microfibre filters Whatman GF/C. Suspensions of synaptic vesicles $(300 \mu \mathrm{g}$ proteins) were incubated $10 \mathrm{~min}$ in the medium of cytosolic fraction of synaptosomes $(1.2 \mathrm{mg} / \mathrm{ml}$ proteins) or buffer solution ( $1 \mathrm{mM}$ EGTA, $10 \mathrm{mM}$ Tris- $\mathrm{HCl}$, $\mathrm{pH}$ 7.5). After incubation the suspensions of synaptic vesicles were centrifuged for $60 \mathrm{~min}$ at 130,000 $\times \mathrm{g}$. Precipitates were perfused with cacodylate buffer $(0.1 \mathrm{M}, \mathrm{pH} 7.2)$ containing $2.5 \%$ glutaraldehyde for $2 \mathrm{~h}$. The synaptic vesicle sediments were post-fixed in the solution $0.05 \mathrm{M}$ cacodylate buffer containing 1\% osmium tetroxide for $60 \mathrm{~min}$, dehydrated in graded acetone and embedded in araldite. Ultra thin slices were mildly stained using uranyl acetate and lead citrate, followed by their examination using the electron microscope Hitachi-600.

\section{Extraction of cholesterol from synaptic vesicles by methyl- $\beta$ - cyclodextrin}

The effect of cholesterol on the process of synaptic vesicle aggregation was carried out in the presence of $15 \mathrm{mM}$ of MCD in incubation medium. The effect of cholesterol on the process of calcium-dependent homotypic fusion of synaptic vesicles was examined after removal MCD from the medium. Briefly, the synaptic vesicle samples $(450 \mu \mathrm{g}$ proteins) in the medium containing $10 \mathrm{mM}$ Tris- $\mathrm{HCl}(\mathrm{pH}$ 7.5) were incubated with 5 and $15 \mathrm{mM} \mathrm{MCD}$ for $30 \mathrm{~min}$ at $37^{\circ} \mathrm{C}$. To remove MCD the synaptic vesicle suspension was passed thought the column with Sephadex G-75.

To determine the cholesterol level of synaptic vesicles, the total lipids of membrane were extracted by method of Bligh and Dyer (1959). Free cholesterol fraction was isolated by thin layer chromatography using the system consisting of benzene/ethyl acetate/acetic acid (85:15:1). After thin layer chromatography, the cholesterol content was determined by gas-liquid chromatography or modified method of Zlatkis et al. (1953).

\section{Detection of membrane fusion by technique with octadecyl rhodamine probe (R18)}

The R18 assay was proposed by Keller and Hoekstra for membrane fusion monitoring and based on the relief of selfquenching of probe fluorescence (Keller et al. 1977; Hoekstra et al. 1984). The probe dilution into the target membrane as a result of its transfer and/or membrane fusion, gives rise to an increase of the fluorescence emission signal. Measure- 
ment of the fluorescence of R18 can provide a continuous and a quantitative assessment of membrane fusion. The membrane fusion was initiated by $10^{-5} \mathrm{M} \mathrm{CaCl}_{2}$ addition. Free $\mathrm{Ca}^{2+}$ concentrations were set by $\mathrm{Ca}^{2+} /$ EGTA buffers as described by Portzehl et al. (1964).

\section{Incorporation of R18 into synaptic vesicles}

The solution of R18 in ethanol was injected into $0.2 \mathrm{ml}$ of synaptic vesicle suspension $(1 \mathrm{mg} / \mathrm{ml}$ of protein) in buffer solution with $10 \mathrm{mM}$ Tris- $\mathrm{HCl}(\mathrm{pH} 7.5)$ and incubated for $5 \mathrm{~min}$ at $37^{\circ} \mathrm{C}$ in the dark. The final concentrations of the probe and ethanol were $20 \mu \mathrm{M}$ and $0.5 \%(\mathrm{v} / \mathrm{v})$, respectively. Unbound R18 was removed on a Sephadex G-75 column. The fluorescence of labeled synaptic vesicles was about 80-90\% quenched. Quenching (Q) was calculated according to $\mathrm{Q}=1-\mathrm{F} / \mathrm{F}_{\max }$, where $\mathrm{F}$ is the fluorescence and $\mathrm{F}_{\max }$ is the fluorescence measured after addition of detergent $\mathrm{C}_{12} \mathrm{E}_{8}$ (octaethyleneglycol-dodecyl ether) at a final concentration of $0.1 \%$. R18-loaded synaptic vesicles were kept on ice in dark until use. This labelled preparation was designated as R18-synaptic vesicles.

\section{Confocal imaging}

The R18 probe was used to visualize the synaptic vesicle interactions by confocal microscopy. The procedure of $\mathrm{R} 18$ incorporation in the synaptic vesicle membrane was the same as described above. The fluorescence image of synaptic vesicle clusters was obtained by laser scanning confocal microscopy LSM 510 META (Carl Zeiss, Germany), objective EC Plan-Neofluar $10 \times / 0.3$. Fluorescence was excited by light from a mercury lamp HBO 100, passed through the Beam Splitters FW1; Fset $10 \mathrm{wf}$ (excitation wavelength around $535 \mathrm{~nm}$ ). Image registration was carried out in a built in microscope digital camera Axio Cam HRc.

\section{Results}

\section{Electron microscopy for characterizing single synaptic} vesicles and vesicle clusters

The fraction of synaptic vesicles was purified by filtering through glass microfibre filters Whatman GF/C and characterized by the presence of vesicular particles that had diameter 40-50 nm (Fig. 1A). When the same synaptic vesicle fraction was placed in the medium containing the cytosolic fraction of synaptosomes $(1.2 \mathrm{mg} / \mathrm{ml}$ proteins), the appearance of particles with diameter $150-300 \mathrm{~nm}$ was visualized (Fig. 1B).

These data confirm the ability of synaptic vesicles to aggregate that was earlier shown by the analysis of particle size distribution performed by dynamic light scattering (DLS) (Trikash et al. 2008). The conformity of data obtained by both approaches allowed us to affirm the phenomenon of synaptic vesicle clustering in vitro.

The synaptosomal cytosolic proteins promote the synaptic vesicle aggregation

The possibility to regulate the clustering of synaptic vesicles in vitro by the use of different amounts of the synaptosomal cytosolic proteins in the media was examined. In experiments performed with using DLS, the fraction of vesicles
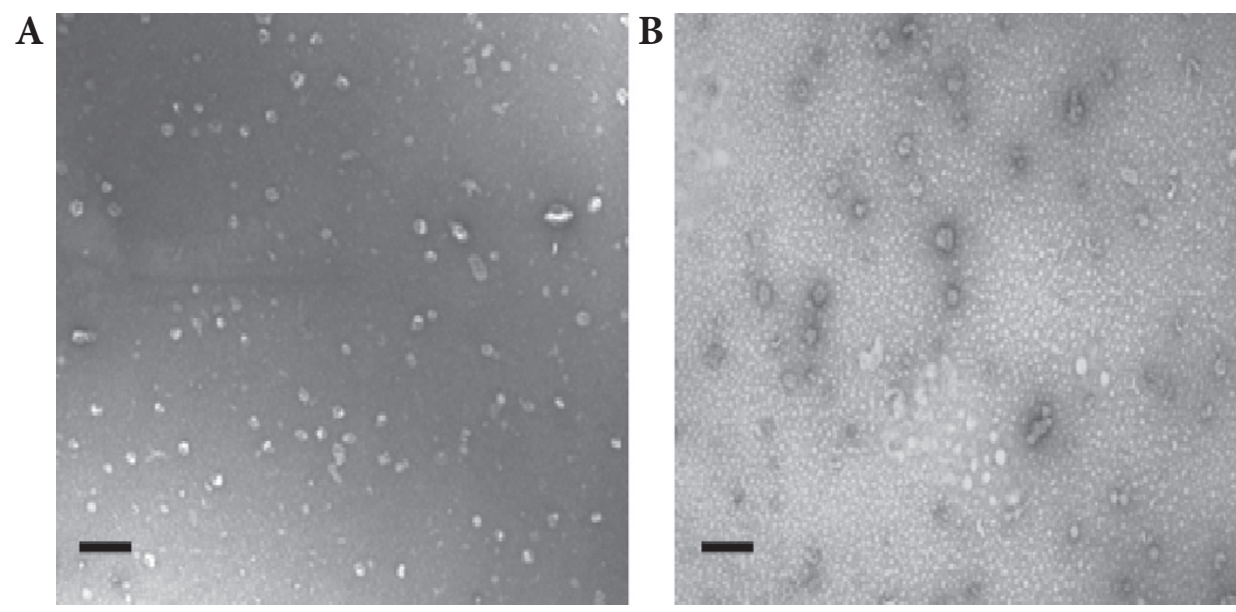

Figure 1. Electron micrographs of the synaptic vesicle fraction in the media containing buffer solution (A) or cytosolic fraction of synaptosomes (B). The synaptic vesicle fraction in the medium containing $10 \mathrm{mM}$ Tris$\mathrm{HCl}(\mathrm{pH}$ 7.5) was purified by filtering through glass microfibre filters Whatman GF/C. Suspensions of synaptic vesicles $(300 \mu \mathrm{g}$ proteins) were incubated $10 \mathrm{~min}$ in buffer solution (1 mM EGTA, $10 \mathrm{mM}$ Tris-HCl, $\mathrm{pH}$ 7.5) or the medium of cytosolic fraction of synaptosomes $(1.2 \mathrm{mg} / \mathrm{ml}$ proteins). Ultrathin slices were mildly stained using uranyl acetate and lead citrate, followed by their examination using the electron microscope Hitachi-600. A, bar $200 \mathrm{~nm}$; B, bar $400 \mathrm{~nm}$. Magnification: 35 000× (A); 17 500× (B). 
was not passed through Whatman filter. Fig. 2 shows the distribution of synaptic vesicles according to diameter in the medium containing buffer solution and cytosolic proteins in different concentrations. The size distribution of particles was in range 30 to $55 \mathrm{~nm}$, when synaptic vesicles were placed in buffer solution that corresponded to the size of single synaptic vesicles (line 1). However, it should be noted that in this medium the particles with average size $450 \mathrm{~nm}$ were also detected. After placing the vesicular suspension in the medium containing synaptosomal cytosolic proteins (protein concentration of $0.3 \mathrm{mg} / \mathrm{ml}$ ) no changes in the particle size distribution were observed (line 2). Further increase of cytosolic protein concentration up to $1.2 \mathrm{mg} / \mathrm{ml}$ causes a significant enlargement of the particle size to $450-750$ nm (line 3).

Thus, the results obtained by DLS indicate that the level of cytosolic proteins is essential for the formation of synaptic vesicle clusters that seems to be a highly specific process.

\section{Reversibility of the synaptic vesicle aggregation process}

The serial dilution of the cytosolic proteins with the appropriate amount of buffer solution was carried out to investigate whether the clusters formed in the presence of the standard protein concentration $(1.2 \mathrm{mg} / \mathrm{ml})$ could be disaggregated. Fig. 3 shows the effect of decreasing the protein concentration on the mean diameter of particles. The aggregation was induced by the application of synaptic vesicle suspension to the solution of synaptosomal cytosolic fraction with protein concentration $1.2 \mathrm{mg} / \mathrm{ml}$. All synaptic vesicles were distributed between the two pools with the mean particle sizes $20-30 \mathrm{~nm}$ and $\sim 480 \mathrm{~nm}$
(Fig. 3, line 1). When concentration of cytosolic proteins decreased to $0.6 \mathrm{mg} / \mathrm{ml}$, particles with a diameter of $480 \mathrm{~nm}$ were still present, but their number was decreased (line 2). At low protein concentration in medium $(0.2 \mathrm{mg} / \mathrm{ml})$, the appreciable changes in particle size distribution were detected (line 3): synaptic vesicle aggregates with particle size diameter $\sim 480 \mathrm{~nm}$ practically disappeared and the number of particles with a diameter of 20-30 nm increased. Therefore, it is likely that concentration of synaptosomal cytosolic proteins is responsible for the stability of synaptic vesicle clusters, and the formation of clusters seems to be a dynamic process.

\section{The influence of black widow spider venom on synaptic vesicle aggregates}

Assuming that the vesicle clusters may contain a large variety of proteins necessary for vesicle recycling with no obvious function determined inside the clusters (Denker et al. 2011), it is of interest to explore the approach proposed by these authors in relation to the effect of black widow spider venom. According to their data black widow spider venom is able to disrupt the vesicle clusters. Using DLS method we also analyzed whether the size of synaptic vesicle aggregates formed in the medium with synaptosomal cytosolic proteins $(1 \mathrm{mg} / \mathrm{ml})$ would be altered after the addition of black widow spider venom.

As shown in Fig. 4A, synaptic vesicle suspension purified from nerve terminals in the medium of synaptosomal cytosolic fraction represent a heterogeneous population, in which there are particles whose size corresponds to the aggregates of synaptic vesicles. The addition of black widow spider venom, the agent affecting synaptic vesicle exocytosis,

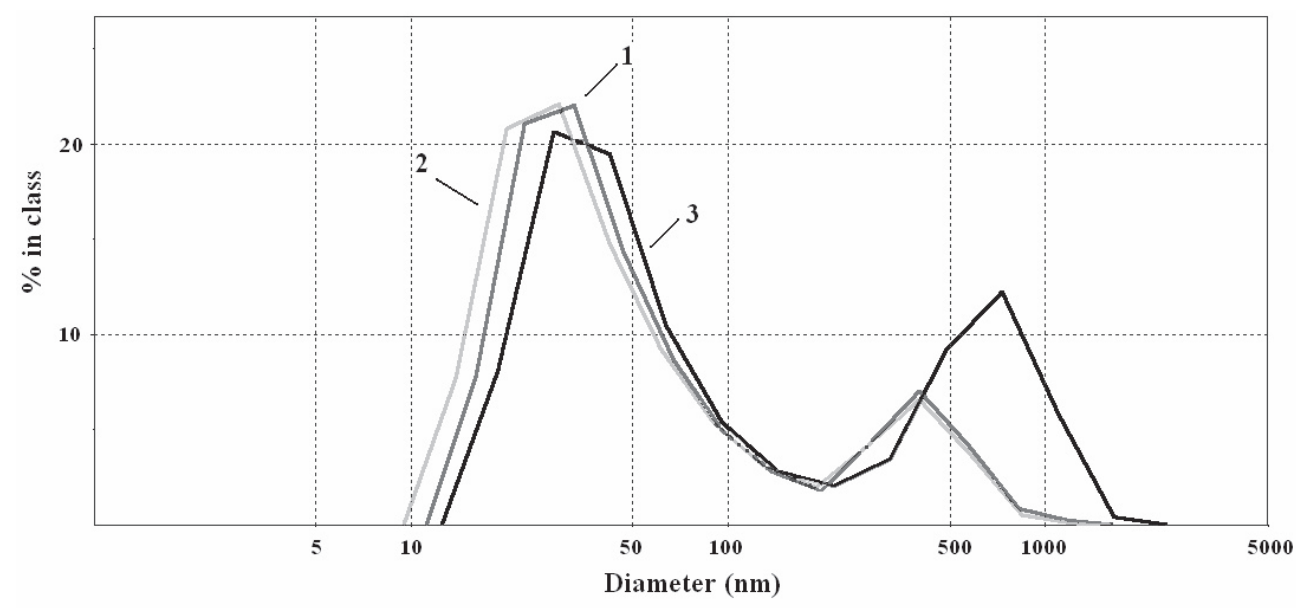
the photon-correlation spectroscopy (PCS) intensity distribution to volume distributions is obtained using the provided software by Malvern Instruments.

Figure 2. Size distribution of particles in synaptic vesicle suspension in the medium of: buffer solution ( $1 \mathrm{mM}$ EGTA, $10 \mathrm{mM}$ Tris- $\mathrm{HCl}$, pH 8.1; line 1), cytosolic fraction of synaptosomes with $0.3 \mathrm{mg} / \mathrm{ml}$ of proteins (line 2) or $1.2 \mathrm{mg} / \mathrm{ml}$ of proteins (line 3). Data are presented as the particle size distribution by volume and analyzed with the Contin algorithm (Malvern Instruments), which calculates the $\mathrm{Z}$-average size and polydispersity. The transforms of persity. The transforms
using the provided software by 


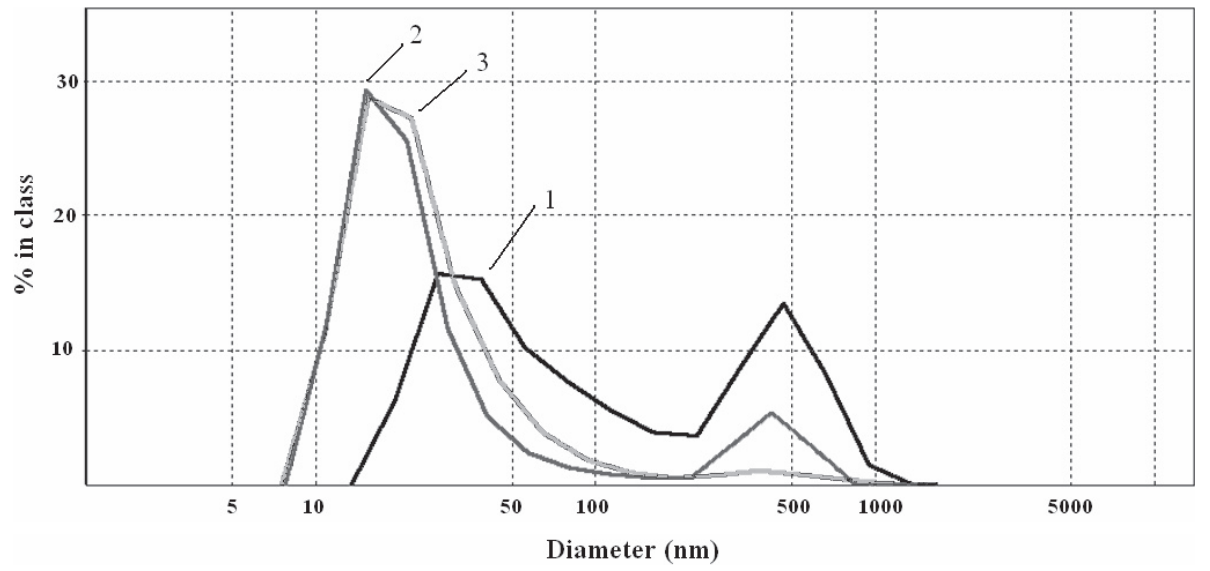

Figure 3. Size distribution of particles in synaptic vesicle suspension in the medium of cytosolic fraction of synaptosomes with $1.2 \mathrm{mg} / \mathrm{ml}$ of proteins (line 1 ), $0.6 \mathrm{mg} / \mathrm{ml}$ of protein (line 2), $0.2 \mathrm{mg} / \mathrm{ml}$ of protein (line 3 ). Data are presented as the particle size distribution by volume and analyzed with the Contin algorithm (Malvern Instruments), which calculates the Z-average size and polydispersity. The transforms of the PCS intensity distribution to volume distributions is obtained using the provided software by Malvern Instruments. causes a rapid disappearance of clusters indicating a frailty of such multivesicular complexes (Fig. 4B).

\section{Antiepileptic drugs as the modulators of synaptic vesicle aggregation}

The aim of the next experiment was to study the in vitro effects of antiepileptic drugs ethosuximide and sodium valproate on process synaptic vesicle aggregation. Laser light scattering measurements show that the addition of ethosuximide to a suspension of synaptic vesicles in the presence of cytosolic fraction of synaptosomes causes changes in the number of particles with a diameter of about $500 \mathrm{~nm}$ (Fig. 5, line 2). Note, the diameter of aggregates was not changed markedly, but their amount increased. When synaptic vesicles were incubated in ethosuximide-free medium, the amount of single nonaggregated particles $(30-45 \mathrm{~nm}$ ) consisted of $22 \%$ (Fig. 5 , line 1) but the ethosuximide injection was accompanied by the decrease in the amount of single synaptic vesicles up to $15 \%$ (Fig. 5 , line 2 ). Thus, the increase in the number of aggregates in the medium took place due to the clustering of single synaptic vesicles as a result of ethosuximide action.

Experiments with antiepileptic drug sodium valproate performed with using the characteristic of the intensity of light scattering revealed a similarity in the action of ethosuximide and sodium valproate on the synaptic vesicle aggregation although these drugs have distinct chemical structures. Fig. 6 shows (line 1) the particle size distribution in synaptic vesicle suspension placed in the medium of synaptosomal cytosolic fraction without drug. The line 2 indicates that the addition of sodium valproate shifts the size of particles to the right (in average on $200 \mathrm{~nm}$ ). Therefore, these results indicate that one of the similarities between the antiepileptic drugs is ability to significantly activate synaptic vesicle aggregation. Cholesterol level reduction and the process of synaptic vesicle
aggregation

Using DLS method we also studied whether a removal of cholesterol from the synaptic vesicles affected the process of synaptic vesicle aggregation when it occurred in the medium with cytosolic fraction of synaptosomes. To modulate the cholesterol content of synaptic vesicles a cholesterol binding agent MCD was used. The cyclodextrin molecules are characterized by the presence of an internal hydrophobic cavity that can accommodate hydrophobic compounds such as cholesterol (Christian et al. 1997).

Fig. 7 demonstrates the distribution of particle sizes in suspension of synaptic vesicles in control (line 1) and after addition of $15 \mathrm{mM}$ MCD (line 2). Although the incubation of synaptic vesicles with $15 \mathrm{mM} \mathrm{MCD}\left(20 \mathrm{~min}, 25^{\circ} \mathrm{C}\right)$ caused about $40 \%$ reduction of cholesterol in membranes, it did not affect the particle size distribution and their amount in the medium. As seen, the particle size distribution remained to be bimodal with modes of $50 \mathrm{~nm}$ and $480 \mathrm{~nm}$. Thus, the removal of cholesterol from synaptic vesicles did not change the process of synaptic vesicle aggregation in cellfree system.

\section{Cholesterol removal from the synaptic vesicles and $\mathrm{Ca}^{2+}$ - initiated homotypic fusion}

Synaptic vesicles with altered level of cholesterol were also used for elucidation the role of membrane cholesterol for homotypic fusion of synaptic vesicles in calcium-controlled process. For partial removal of cholesterol, the synaptic vesicles were incubated for $30 \mathrm{~min}$ at $25^{\circ} \mathrm{C}$ with 5 or $15 \mathrm{mM}$ MCD. As a result, a level of cholesterol in synaptic vesicles was decreased compared to the control level by $20 \%$ or $40 \%$, respectively.

Membrane fusion between synaptic vesicles was monitored by R18 assay that was described in section of experi- 


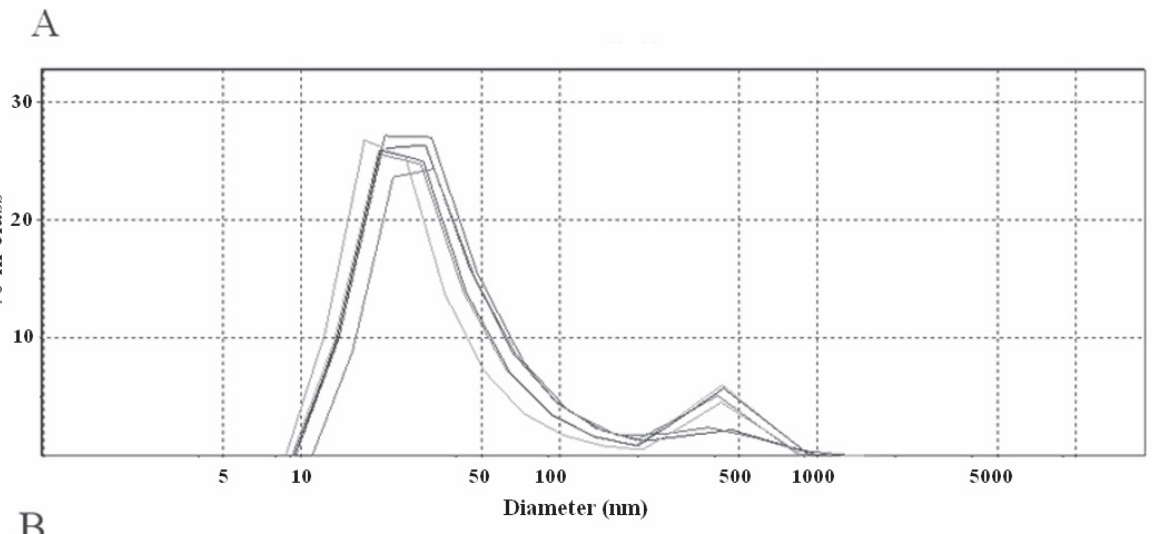

B

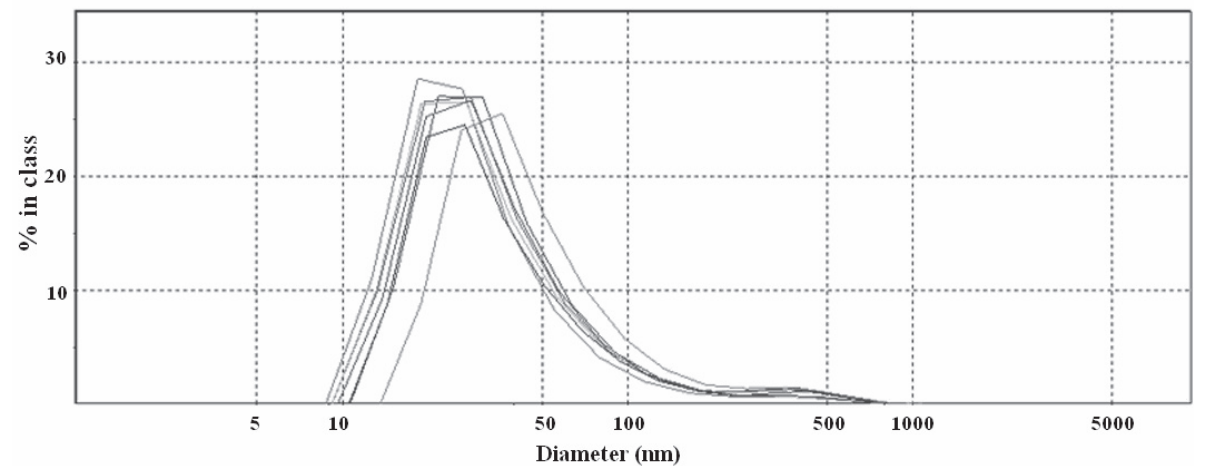

Figure 4. The effect of black widow spider venom on synaptic vesicle aggregates. The particle size distribution before (A) and after adding black widow spider venom (B). The suspension of synaptic vesicles (100 $\mu$ g of proteins) was injected to the medium with cytosolic fraction of synaptosomes $(1.0 \mathrm{mg} / \mathrm{ml}$ of proteins, $10 \mathrm{mM}$ Tris- $\mathrm{HCl}, \mathrm{pH}$ 8.1). After DLS measurement of this system (A) was added $20 \mu \mathrm{g}$ of black widow spider venom and measured again (B). Data are presented as the particle size distribution by volume and analyzed with the Contin algorithm (Malvern Instruments), which calculates the $\mathrm{Z}$-average size and polydispersity. The transforms of the PCS intensity distribution to volume distributions is obtained using the provided software by Malvern Instruments. mental procedures. The R18 fluorescence assay validity to examine the fusion of synaptic vesicle membranes in cellfree system was previously described (Trikash et al. 2010). It was shown at least two simultaneous processes, one of which is attributed to real fusion of membranes, while the other is considered to be non-specific probe transfer. The second reaction is much slower than the first one and needs much more time to rich its maximum value. The measurements in Fig. 8 were submitted without subtracting non-specific transfer of the probe in the absence of calcium, because during this period of time the transfer of the probe was negligible.

The addition of calcium to the suspension of control synaptic vesicles leads to the increase in the membrane fusion

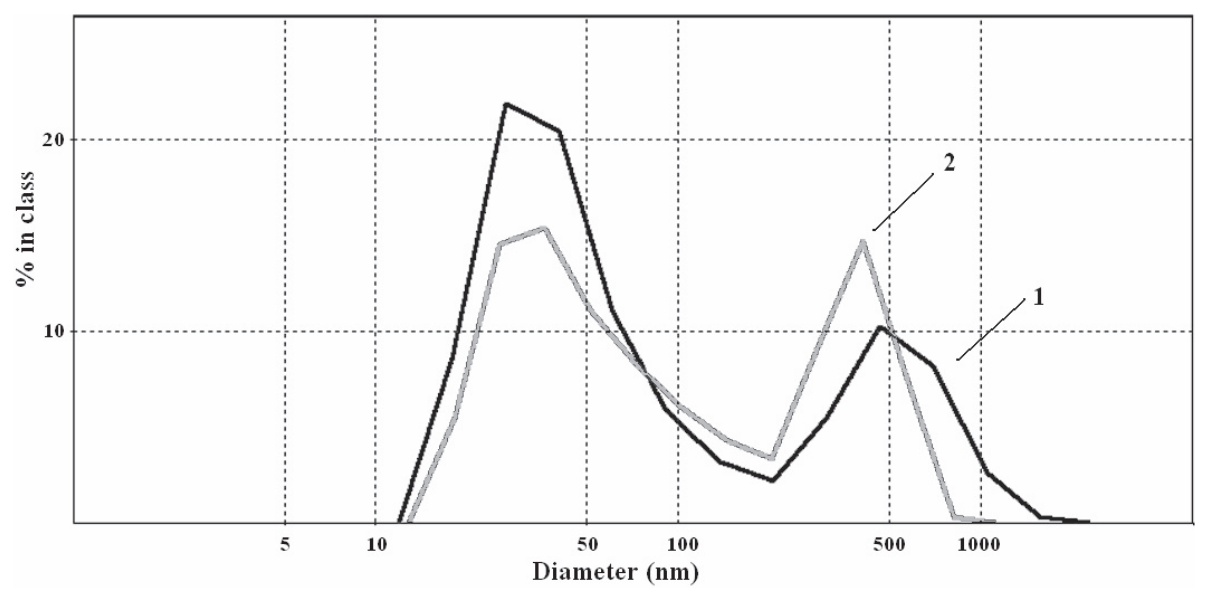

Figure 5. The effect of ethosuximide on synaptic vesicle aggregation. The suspension of synaptic vesicles $(100 \mu \mathrm{g}$ of proteins) in the presence of cytosolic fraction of synaptosomes (1.0 mg of proteins/ $\mathrm{ml}, 10 \mathrm{mM}$ Tris-HCl, $\mathrm{pH}$ 8.1) without (line 1) or with the addition of $2 \mathrm{mg} / \mathrm{ml}$ ethosuximide ( $14 \mathrm{mM}$ ) - line 2. Data are presented as the particle size distribution by volume and analyzed with the Contin algorithm (Malvern Instruments), which calculates the Z-average size and polydispersity. The transforms of the PCS intensity distribution to volume distributions is obtained using the provided software by Malvern Instruments. 


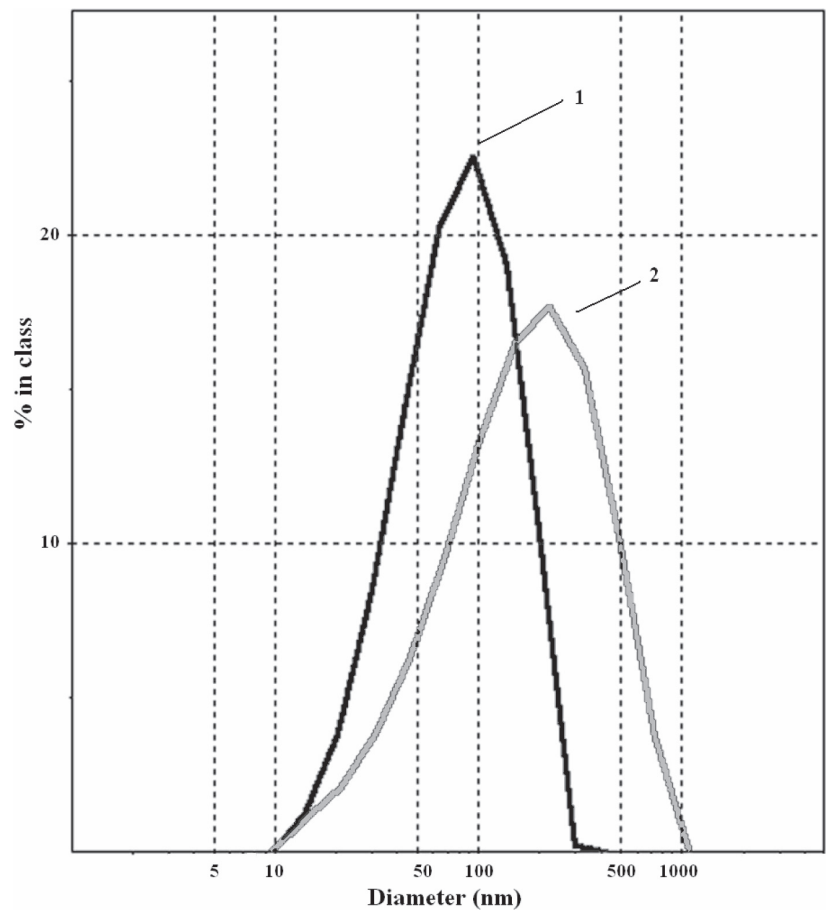

Figure 6. The action of sodium valproate on synaptic vesicle aggregation in cell-free system. The particle size distribution of synaptic vesicle suspension ( $100 \mu \mathrm{g}$ of proteins) in the presence of cytosolic fraction of synaptosomes $(1.0 \mathrm{mg}$ of proteins $/ \mathrm{ml}$, $10 \mathrm{mM}$ Tris-HCl, $\mathrm{pH} 8.1$ ) - line 1; after addition of $14 \mathrm{mM}$ of sodium valproate - line 2. Data are presented as the particle size distribution by intensity of light scattering and analyzed with the Contin algorithm (Malvern Instruments), which calculates the Z-average size and polydispersity. to $20 \%$ of the maximum after 4 minutes time (Fig. 8 , curve $1)$. At the same time the rates of the synaptic vesicle homotypic fusion reached $15 \%$ and $10 \%$ of the maximum under the removal of $20 \%$ and $40 \%$ of cholesterol correspondingly (curves 2 and 3 ).

Thus, it is shown that the reduction of cholesterol level in synaptic vesicles inhibits the $\mathrm{Ca}^{2+}$-dependent fusion of their membranes, which may be due to dysfunction of the proteins that mediate this process.

The kinetics of membrane fusion represented by the curves in Fig. 8 can be analytically approximated by a parametric family of characteristics of $\mathrm{I}_{\mathrm{fl}}(\%)=\mathrm{f}\left(\mathrm{t}_{\min }\right)$, described by the expression:

$$
\mathrm{I}_{\mathrm{fl}}(\%)=\left(12.2-15.0 \mathrm{p}_{\text {chol }}\right) \ln \left(\mathrm{t}_{\min }\right)+\left(0.9-1.7 \mathrm{p}_{\text {chol }}\right)
$$

where $\mathrm{p}_{\mathrm{chol}}$ is the concentration of cholesterol in the range 0 ... 1, i.e. $\mathrm{p}_{\text {chol }}=0.2 \rightarrow 20 \%$. Thus, knowing the level of cholesterol depletion from the synaptic vesicle membranes and using the Eq. 1, it is possible to calculate the kinetics of fusion of synaptic vesicles under specified conditions of this model system.

\section{Visualization of synaptic vesicle clustering by confocal microscopy}

For visualization of synaptic vesicle interactions by confocal microscopy the fluorescence probe R18 was used. The probe $\mathrm{R} 18$ was inserted into the membranes of synaptic vesicles at a concentration of self-quenching fluorescence. The experiments were performed by injection of the sus-

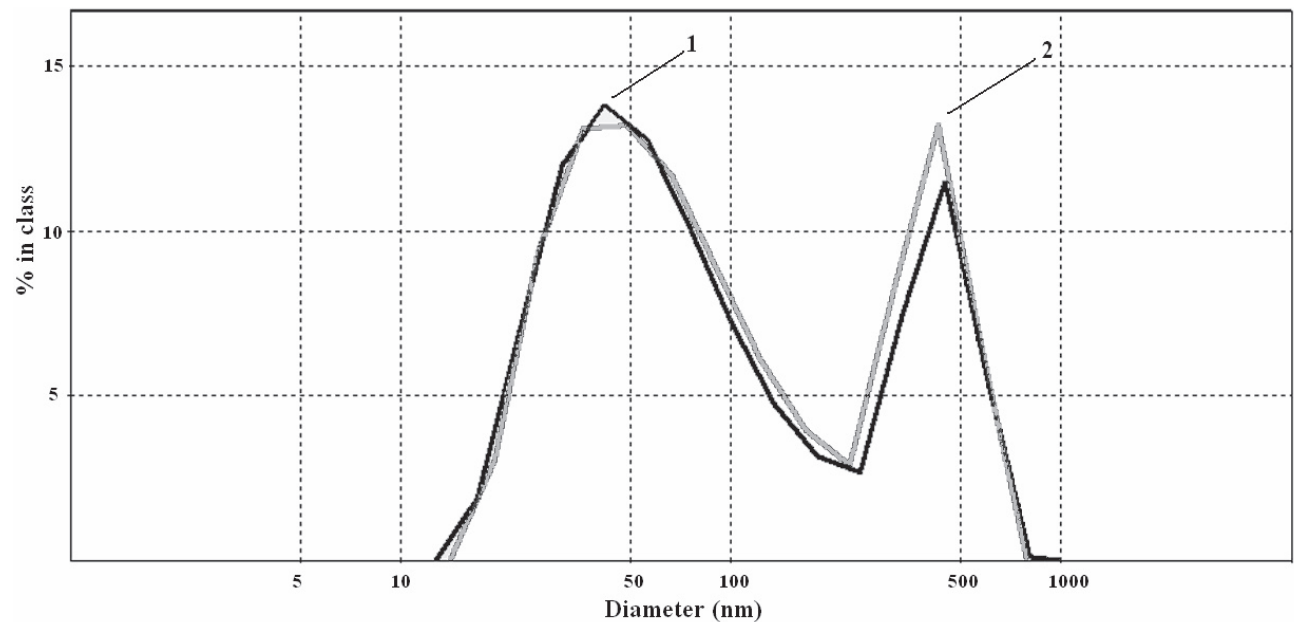
distribution by volume and analyzed with the Contin algorithm (Malvern Instruments), which calculates the Z-average size and polydispersity. The transforms of the PCS intensity distribution to volume distributions is obtained using the provided software by Malvern Instruments.
Figure 7. Distribution of particles size in synaptic vesicle suspension. $200 \mu \mathrm{l}$ of synaptic vesicle suspension $(0.8 \mathrm{mg} / \mathrm{ml}$ of protein $)$ was injected in the medium containing $800 \mu \mathrm{l}$ of synaptosomal cytosolic fraction $(1 \mathrm{mg} / \mathrm{ml}$ of protein, line 1 - without MCD, line 2 - after the incubation with $15 \mathrm{mM}$ MCD for $20 \mathrm{~min}$ at room temperature. Data are presented as the particle size
the $\mathrm{Z}$-average size and poly$10 \mathrm{mM}$ Tris- $\mathrm{HCl}, \mathrm{pH} 8.1$ ): 
pension of synaptic vesicles, consisting of the R18-labelled vesicles and R18-free vesicles (ratio by protein concentration $1: 8$, respectively) into the medium containing the cytosolic fraction of synaptosomes (Fig. 9A). As seen, in such system, under conditions that lead to synaptic vesicle aggregation, scanning confocal microscope does not detected any fluorescence that indicates that the probe remains in self-quenching concentration of fluorescence. The appearance of luminous structures reflects the calcium induced fusion of synaptic vesicles and is the result of the probe fluorescence dequnching after its redistribution in the fused membranes (Fig. 9B). Thus, these experiments are the additional confirmation of the thesis that the process of vesicle cluster formation is not spontaneously turned to the process of synaptic vesicle membrane fusion.

\section{Discussion}

During assembly the membranes are pulled very closely together that is a prerequisite for initiating fusion (Hanson et al. 1997; Lin and Scheller 1997). The mechanisms by which synaptic vesicles might be held together in the clusters were discussed as the function of proteins located within the synaptic vesicle clusters (Shupliakov 2009). The idea that aggregation of synaptic vesicles is required for $\mathrm{Ca}^{2+}$-dependent compound exocytosis was confirmed by the sequence of modelled events. The significant increase of particles size in the suspension of synaptic vesicles in the medium of synaptosomal cytosolic fraction was determined by dynamic light scattering. Thus, the proteins of synaptosomal cytosolic fraction were shown to promote the vesicle close proximity that underlies the formation of vesicle aggregates. Such phenomenon was defined as a docking state between synaptic vesicles (Trikash et al. 2008). While the proteins present on synaptic vesicles have been systematically identified (Takamori et al. 2006), none of these have been assigned to as a docking factor.

Note, that docked vesicles are traditionally defined as those vesicles that have no measurable distance between their membranes. Synaptic vesicle docking were observed in electron micrographs of the synapse and defined as the attachment of vesicles to their target membranes (Schikorski and Stevens 2001) and seen as electron-dense structures (Verhage and Sorensen 2008). The presence of synaptic vesicle clusters in media of synaptosomal cytosolic fraction was confirmed by electron microscopy (Fig. 1B). It should be noted that the purified synaptic vesicle fraction in a buffer medium was received after passing through the Whatman GF/C filter. Direct microscope observation of this vesicular fraction showed single non-aggregated spheres, with the size similar to the size of synaptic vesicles (Fig 1.A). It was important if vesicle suspension did not pass through

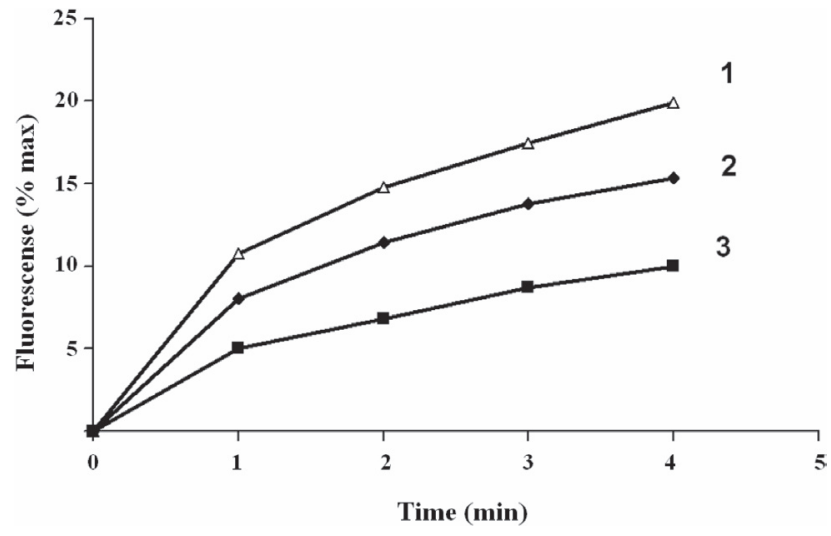

Figure 8. The decrease in the intensity of calcium-induced fusion of synaptic vesicles after partial elimination of cholesterol from the membranes. The suspensions of non-labelled synaptic vesicles ( $80 \mu$ g of protein) (curve 1, control) and synaptic vesicles whose cholesterol was decreased by $20 \%$ (curve 2) or $40 \%$ (curve 3 ) were added to $1 \mathrm{ml}$ of cytosolic proteins of synaptosomes $(1 \mathrm{mg} / \mathrm{ml}$ of protein) with $10 \mu \mathrm{l}$ of suspension of R18-containing synaptic vesicles ( $8 \mu \mathrm{g}$ of protein). The membrane fusion was initiated by the addition of $10^{-5} \mathrm{M} \mathrm{Ca}^{2+}$.

Whatman filter that contained not only single particles, but also their assemblies as shown by dynamic light scattering measurements (Fig. 2, line 2). Therefore, the observed increase in size of the particles that took place in the absence of any cytosolic proteins appears to be a direct result of the synaptic vesicle interaction in the intact synapses before their destruction. The presence of tight clusters of synaptic vesicles is common for these inter-neuronal junctions in different vertebrate species ( $\mathrm{Li}$ et al. 1995; Pieribone et al. 1995). On average, only $2-3$ vesicles are docked and 5 single vesicles are within $20 \mathrm{~nm}$ of active zone (Satzler et al. 2002; Taschenberger et al. 2002).

In accordance with the protein buffering hypothesis, the amount of soluble protein on the vesicles should rise when the vesicles are placed in contact with the source of soluble proteins (such as cytosol) (Denker et al. 2011). We have shown that in the process of interaction or joining the vesicles approach each other and form a rather stable intermediate complex, which can be detected by measuring the light scattering. Here, tested the role of cytosolic proteins of synaptosomes in docking process of synaptic vesicles by reducing their effective concentrations and thus causing a critical situation for the interactions with their binding partners on synaptic vesicle membranes (Fig. 2). It was established that the aggregation or docking effect of synaptic vesicles (as well as previously shown calcium-induced fusion of the synaptic vesicles (Trikash and Kolchinska 2006)) depends on the protein concentration in the synaptosomal cytosolic fraction. Recent evidence suggests there are several classes of 
proteins that induce the initial contact between membranes but they are not involved in the fusion reaction itself. For instance, a trimeric complex consisting of mammalian Unc13 homolog (Munc13), Rab3 and Rab3-interacting molecule (RIM) has been postulated to recruit synaptic vesicles to the presynaptic membrane (Dulubova et al. 2005) and serve as a docking factor that together with syntaxin-1 forms the minimal docking machinery (de Wit et al. 2009). The role of the cytosolic proteins in vesicle aggregation is supported by impaired dense core granule docking in adrenal chromaffin cells of Munc18-1 knockout mice (Ciufo et al. 2005). Several observations suggest that SM-proteins function also at a late postdocking stage of membrane fusion (Diao et al. 2010). However, the way how soluble protein factors activate membrane interactions remains unclear in part due to the inability to analyze an ensemble of mergers and the distinguishing of its various stages in vitro.

Therefore, in this manuscript, we focus on the reversibility of synaptic vesicle aggregation, in which close contact between membranes lead to the clustering but not to the fusion. A serial dilution for decreasing the concentration of cytosolic proteins in medium resulted in a significant decrease in the number of synaptic vesicle aggregates previously formed in conditions of a higher protein concentration (Fig. 3). It should be noted that at concentration of $0.2 \mathrm{mg}$ of protein per $1 \mathrm{ml}$ of the final disaggregation of clusters with a size of $480 \mathrm{~nm}$ does not occur. Thus, the manipulation by cytosolic protein concentrations involved in the exocytotic machinery of model system leads to the detectable and interpretable changes in the synaptic vesicle interactions. Consequently, the stability of synaptic vesicle clusters depends on the protein concentration of synaptosomal cytosolic fraction in the cell-free system and reflects the reversible contact between synaptic vesicles. It is of interest that the vesicle clusters formed in vitro were destroyed by the action of the black widow spider venom (Fig. 4) that is consistent with the result of Denker et al. 2011. These findings are associated with the disruption of synaptic vesicle clusters due to black widow spider venom applied and following diffusion of numerous soluble proteins into the axon.

Earlier, in cell free system we have revealed the significant modulating action of ethosuximide and sodium valproate on calcium-induced fusion of synaptic vesicles with plasma membranes and their capability to activate the homotypic synaptic vesicle fusion process (Trikash et al. 2003; Gumenyuk et al. 2009). Multiply evidences suggest that more than one molecular target for antiepileptic drugs (AEDs) with broad spectrum clinical activity has been demonstrated (White et al. 2007). The present study shows that ethosuximide and sodium valproate activate the synaptic vesicle aggregation in the medium containing the synaptosomal cytosolic fraction and, therefore, are responsible for intensification of synaptic vesicle clustering (Fig. 5, 6). Our finding suggests the involvement of AEDs in the exocytosis at the synaptic vesicle docking step that precedes their multivesicular fusion. Hence, the AEDs are influenced not only on the fusion of synaptic vesicles with the plasma membrane (i.e. simple exocytosis), but also on the synaptic vesicle docking and their membrane fusion (i.e. multivesicle compound exocytosis). Conversely, the effects of ethosuximide and sodium valproate on the increasing of size particles in the system were negligible (data not shown) when the synaptosomal cytosolic proteins were not present in the medium. These data corroborated by the findings that AEDs did not change the intensity of calciumdependent fusion of liposomes or synaptic vesicles treated by proteases (Gumenyuk et al. 2009). Therefore, we suggest
A

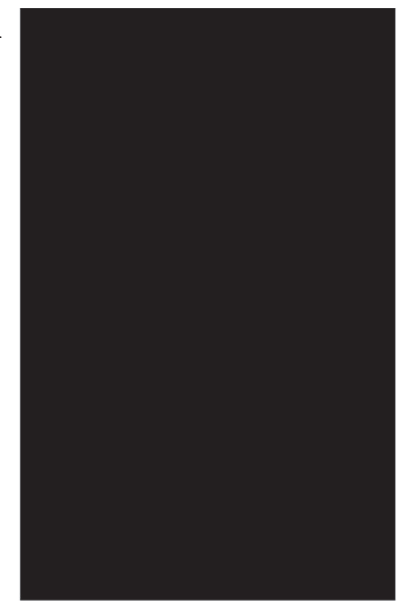

B

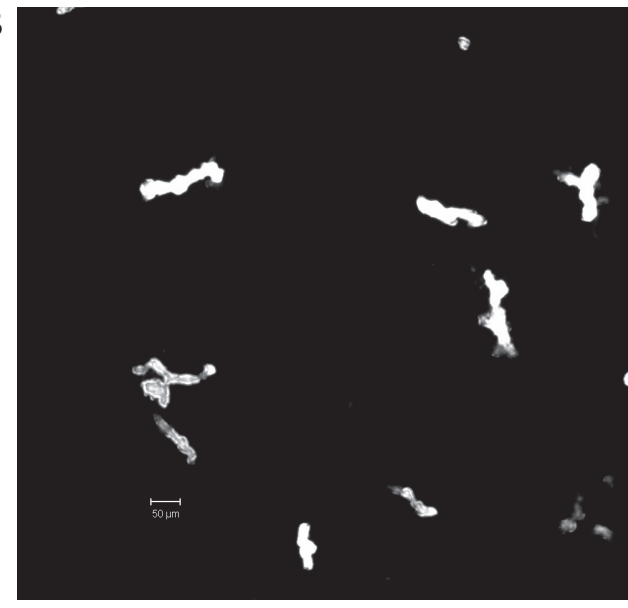

Figure 9. Confocal image of synaptic vesicle suspensions consisting of labelled probe $\mathrm{R} 18$ vesicles and unlabelled vesicles in a medium containing the cytosolic fraction of synaptosomes: without $\mathrm{Ca}^{2+}(\mathbf{A})$, after $10^{-5} \mathrm{M} \mathrm{Ca}^{2+}$ addition (B). The procedure of R18 incorporation in the synaptic vesicle membranes was the same as described in methods. The fluorescence image of synaptic vesicle clusters was obtained by laser scanning confocal microscopy LSM 510 META (Carl Zeiss, Germany), objective EC Plan-Neofluar $10 \times / 0.3$. Fluorescence was excited by light from a mercury lamp HBO 100, passed through the Beam Splitters

FW1; Fset $10 \mathrm{wf}$ (excitation wavelength around $535 \mathrm{~nm}$ ). Image registration was carried out in a built in microscope digital camera Axio Cam HRc. Magnification 1000×, bar $50 \mu \mathrm{m}$. 
that synaptic vesicle membrane proteins and cytosolic fraction proteins are the major executors in clustering process exposed to AEDs in vitro. Thus, this novel scheme of the AEDs action during simple and compound exocytosis may be implicated for testing of new neuroprotective agents.

Previous studies have demonstrated that disbalance of cholesterol can seriously compromise or even abrogate neurotransmission. Cholesterol has been proposed to play a critical role in regulating the secretory machinery at the nerve terminals and synaptic plasticity. Evidence from neuroendocrine PC12 cells (Thiele et al. 2000) and primary neurons (Mauch et al. 2001) suggests that the cholesterol content of membrane is critical for clustering of synaptic vesicle proteins, synaptic vesicle fusion sites and their endocytic recycling (Martin 2000). The cholesterol at its native state may indirectly modulate interactions between t-SNARE proteins and other proteins of the neuronal machinery (Cho et al. 2007). These are consistent with previous findings of a large reduction in induced synaptic transmission in methyl-cyclodextrin treated crayfish neuromuscular junctions and hippocampal neurons (Zamir and Charlton 2006; Rosa and Fratangeli 2010). Besides, in cholesterol-depleted synaptosomes, the exocytotic release of glutamate stimulated by calcium was decreased (Borisova et al. 2010a). Cholesterol depletion also caused: an enhancement of ambient level and transporter-mediated release of glutamate in rat brain nerve terminals (Borisova et al. 2010b); a decrease in acidification of synaptic vesicles and secretory granules in rat brain nerve terminals and blood platelets, respectively (Tarasenko et al. 2010; Borisova et al. 2011). The decreasing level of synaptosomal plasma membrane cholesterol by $8 \%$ leads to suppression of the $\mathrm{Ca}^{2+}$-dependent membrane fusion with synaptic vesicles in cell-free system (Humeniuk and Trykash 2011). According to the present data, the process of synaptic vesicle aggregation is not sensitive to decreasing of cholesterol content in vesicular membranes, whereas such a modification of synaptic vesicle membranes selectively attenuates the $\mathrm{Ca}^{2+}$-triggered synaptic vesicle fusion (Fig. 7, 8).

The rates of calcium stimulated membrane fusion in cellfree system, consisting of homotypic membrane of synaptic vesicles were demonstrated in Fig. 8. Taken together, our results shown that synaptic vesicles are fusion competent in both model systems where the synaptic vesicles could fuse with each other (homotypic membranes) or with synaptosomal plasma membranes (heterotypic membranes) (Trikash 2004, 2006). It is well known that all membrane fusion reactions are mediated by the SNARE core complex and Rab proteins function (Jahn and Sudhov 1999). It was shown that syntaxin and SNAP-25 (the main proteins of SNARE complex) are localized not only at the plasma membrane of presynaptic terminals, but also on synaptic vesicles (Takamori et al. 2006). Thus, the stimulated synaptic vesicle fusion reaction in heterotypic or homotypic membrane sys- tems allows us to interpret the process of membrane fusion in terms of its universality.

It was shown that the homotypic fusion of ribbon-tethered vesicles to each other, triggered by a strong $\mathrm{Ca}^{2+}$ signal at the active zone, has been suggested as a possible mechanism underlying coordinated multivesicular release at the ribbon synapse (Heidelberger et al.1994; Glowatzki and Fuchs 2002; Edmonds et al. 2004; Neef et al. 2007). Moreover, the multivesicular release also occurs at conventional synapses (Tong and Jahr 1994; Wadiche and Jahr 2001; Oertner et al. 2002) and may be coordinated by $\mathrm{Ca}^{2+}$-induced $\mathrm{Ca}^{2+}$ release (Llano et al. 2000). Based on our results a provocative hypothesis for the functioning of the compound exocytosis in nerve synapses can be proposed.

Earlier we investigated the octadecyl rhodamine B chloride (R18) assay validity for the examining of $\mathrm{Ca}^{2+}$-dependent synaptic vesicle fusion with target membranes (Trikash et al. 2010). The confocal microscopy studies of the R18 fluorescence offered a unique opportunity for the visualization of synaptic vesicles. The results obtained by confocal microscopy with the R18 probe strongly confirm the conclusion that synaptic vesicles in the presence of synaptosomal cytosolic proteins do not fused spontaneously. In the medium of synaptosomal cytosolic fraction without calcium it is not possible to image the synaptic vesicle clusters due to absence of R18 fluorescence signal (Fig. 9A). It was expected the appearance of fluorescent signal in confocal microscopy due to R18 dequenching after calcium-induced synaptic vesicle membrane fusion. So, in confocal microscopy, the visualization of synaptic vesicles (the smallest organelles in the cells) was possible only in the form of their fluorescent clusters which accompanied by membranes bilayer mixing (Fig. 9B). It appears that the $\mathrm{Ca}^{2+}$-induced formation of large clusters of synaptic vesicles could be considered as a necessary step of the compound exocytosis.

The described principles laid out here for the clustering of synaptic vesicles as an individual stage of compound exocytosis may differ from some of these other instances, because it is kept in mind that the in vitro system are not necessarily to provide the full reconstruction of the process studied.

In general, as a first approximation, the path of the synaptic vesicle merger can be divided into two stages. First, collected synaptic vesicles in the synaptosomal cytosolic proteins form a docked, but yet unfused intermediates where the lipids of the two membranes are not mixed, and second, when the mixing of synaptic vesicle lipids has occurred.

\section{References}

Belmonte S. A., Lopez C. I., Roggero C. M., De Blas G. A., Tomes C. N., Mayorga L. S. (2005): Cholesterol content regulates 
acrosomal exocytosis by enhancing Rab3A plasma membrane association. Dev. Biol. 285, 393-408 http://dx.doi.org/10.1016/j.ydbio.2005.07.001

Benfenati F., Greengard P., Brunner J., Bahler M. (1989): Electrostatic and hydrophobic interactions of synapsin I and synapsin I fragments with phospholipid bilayers. J. Cell Biol. 108, 1851-1862 http://dx.doi.org/10.1083/jcb.108.5.1851

Bligh E. G., Dyer W. J. (1959): A rapid method of total lipid extraction and purification. Can. J. Biochem. Physiol. 37, 911-917 http://dx.doi.org/10.1139/o59-099

Borisova T., Krisanova N., Sivko R., Borysov A. (2010a): Cholesterol depletion attenuates tonic release but increases the ambient level of glutamate in rat brain synaptosomes. Neurochem. Int. 56, 466-478 http://dx.doi.org/10.1016/j.neuint.2009.12.006

Borisova T., Sivko R., Borysov A., Krisanova N. (2010b): Diverse presynaptic mechanisms underlying methyl-beta-cyclodextrin - mediated changes in glutamate transport. Cell. Mol. Neurobiol. 30, 1013-1023 http://dx.doi.org/10.1007/s10571-010-9532-x

Borisova T., Kasatkina L., Ostapchenko L. (2011): The proton gradient of secretory granules and glutamate transport in blood platelets during cholesterol depletion of the plasma membrane by methyl- $\beta$-cyclodextrin. Neurochem. Int. 59, 965-975 http://dx.doi.org/10.1016/j.neuint.2011.07.007

Brunham L. R., Kruit J. K., Verchere C. B., Hayden M. R. (2008): Cholesterol in islet dysfunction and type 2 diabetes. J. Clin. Invest. 118, 403-408 http://dx.doi.org/10.1172/JCI33296

Chintagari N. R., Jin N., Wang P., Narasaraju T. A., Chen J., Liu L. (2006): Effect of cholesterol depletion on exocytosis of alveolar type II cells. Am. J. Respir. Cell. Mol. Biol. 34, 677-687 http://dx.doi.org/10.1165/rcmb.2005-0418OC

Cho W. J., Jeremic A., Jin H., Ren G., Jena B. P. (2007): Neuronal fusion pore assembly requires membrane cholesterol. Cell. Biol. Int. 31, 1301-1308 http://dx.doi.org/10.1016/j.cellbi.2007.06.011

Christian A. E., Haynes M. P., Phillips M. C., Rothblat G. H. (1997): Use of cyclodextrins for manipulating cellular cholesterol content. J. Lipid. Res. 38, 2264-2272

Churchward M. A., Rogasevskaia T., Hofgen J., Bau J., Coorssen J. R. (2005): Cholesterol facilitates the native mechanism of Ca2+ -triggered membrane fusion. J. Cell. Sci. 118, 4833-4848 http://dx.doi.org/10.1242/jcs.02601

Ciufo L. F., Barclay J. W., Burgoyne R. D., Morgan A. (2005): Munc18-1 regulates early and late stages of exocytosis via syntaxin-independent protein interactions. Mol. Biol. Cell. 16, 470-482 http://dx.doi.org/10.1091/mbc.E04-08-0685

de Lorenzo R. J., Freedman S. D. (1978): Calcium dependent neurotransmitter release and protein phosphorylation in synaptic vesicles. Biochem. Biophys. Res. Commun. 80, 183-192 http://dx.doi.org/10.1016/0006-291X(78)91121-X

de Lores Arnaiz G. R., Alverci M., de Robertis E. (1967): Ultrastructural and enzymic studies of cholinergic and noncholinergic synaptic membranes isolated from brain cortex. J. Neurochem. 14, 215-225 http://dx.doi.org/10.1111/j.1471-4159.1967.tb05897.x

de Wit H., Cornelisse L. N., Toonen R. F., Verhage M. (2006):

Docking of secretory vesicles is syntaxin dependent. PLoS One 27, e126

http://dx.doi.org/10.1371/journal.pone.0000126

de Wit H., Walter A. M., Milosevic I., Gulyas-Kovacs A., Riedel D., Sorensen J. B., Verhage M. (2009): Synaptotagmin-1 docks secretory vesicles to syntaxin-1/SNAP-25 acceptor complexes. Cell 138, 935-946 http://dx.doi.org/10.1016/j.cell.2009.07.027

Denker A., Krohnert K., Buckers J., Neher E., Rizzoli S. O. (2011): The reserve pool of synaptic vesicles acts as a buffer for proteins involved in synaptic vesicle recycling. PNAS 108, 17183-17188 http://dx.doi.org/10.1073/pnas.1112690108

Diao J., Su Z., Lu X., Yoon T. Y., Shin Y. K., Ha T. (2010): Singlevesicle fusion assay reveals munc18-1 binding to the snare core is sufficient for stimulating membrane fusion. ACS Chem. Neurosci. 1, 168-174 http://dx.doi.org/10.1021/cn900034p

Dulubova I., Lou X., Lu J., Huryeva I., Alam A., Schneggenburger R., Sudhof T. C., Rizo J. (2005): A Munc13/RIM/Rab3 tripartite complex:from priming to plasticity? EMBO J. 24, 2839-2850 http://dx.doi.org/10.1038/sj.emboj.7600753

Dulubova I., Khvotchev M., Liu S., Huryeva I., Sudhof T. C., Rizo J. (2007): Munc18-1 binds directly to the neuronal SNARE complex. PNAS 104, 2697-2702

http://dx.doi.org/10.1073/pnas.0611318104

Edmonds B. W, Gregory F. D., Schweizer F. E. (2004): Evidence that fast exocytosis can be predominantly mediated by vesicles not docked at active zones in frog saccular hair cells. J. Physiol. (Lond) 560, 439-450 http://dx.doi.org/10.1113/jphysiol.2004.066035

Epand R. M. (2006): Cholesterol and the interaction of proteins with membrane domains. Prog. Lipid Res. 45, 279-294 http://dx.doi.org/10.1016/j.plipres.2006.02.001

Fernandez-Busnadiego R., Zuber B., Maurer U. E., Cyrklaff M., Baumeister W., Lucic V. (2010): Quantitative analysis of the native presynaptic cytomatrix by cryoelectron tomography. J. Cell. Biol. 188, 145-156 http://dx.doi.org/10.1083/jcb.200908082

Glowatzki E., Fuchs P. A. (2002): Transmitter release at the hair cell ribbon synapse. Nat. Neurosci. 5, 147-154 http://dx.doi.org/10.1038/nn796

Gumenyuk V. P., Volinets G. P., Kuchmerovskaya T. M., Trikash I. O. (2009): Effects of antiepileptic agents on homotypic fusion of synaptic vesicles. Neurophysiology 41, 395-403 http://dx.doi.org/10.1007/s11062-010-9118-8

Hanson P. I., Roth R., Morisaki H., Jahn R., Heuser J. E. (1997): Structure and conformational changes in NSF and its membrane receptor complexes visualized by quick-freeze/deep-etch electron microscopy. Cell 90, 523-535 http://dx.doi.org/10.1016/S0092-8674(00)80512-7

Heidelberger R., Heinemann C., Neher E., Matthews G. (1994): Calcium dependence of the rate of exocytosis in a synaptic terminal. Nature. 371, 513-515 http://dx.doi.org/10.1038/371513a0 
Hoekstra D., de Boer T., Klappe K., Wilschut J. (1984): Fluorescence method for measuring the kinetics of fusion between biological membranes. Biochemistry 23, 5675-5681 http://dx.doi.org/10.1021/bi00319a002

Humeniuk V. P., Trykash I.O. (2011): Exocytotic steps in cell-free system after cholesterol deprivation in synaptosomal plasma membranes and synaptic vesicles. Ukr. Biokhim. Zh. 83, 53-64

Jahn R., Südhof T. C. (1999): Membrane fusion and exocytosis. Annu. Rev Biochem. 68, 863-911 http://dx.doi.org/10.1146/annurev.biochem.68.1.863

Keller P. M., Person S., Snipes W. (1977): A fluorescence enhancement assay of cell fusion. J. Cell. Sci. 28, 167-177

Li L., Chin L. S., Shupliakov O., Brodin L., Sihra T. S., Hvalby O., Jensen V., Zheng D., McNamara J. O., Greengard P. (1995): Impairment of synaptic vesicle clustering and of synaptic transmission, and increased seizure propensity, in synapsin I-deficient mice. PNAS 92, 9235-9239 http://dx.doi.org/10.1073/pnas.92.20.9235

Lin R. C., Scheller R. H. (1997): Structural organization of the synaptic exocytosis core complex. Neuron 19, 1087-1094 http://dx.doi.org/10.1016/S0896-6273(00)80399-2

Llano I., Gonzalez J., Caputo C., Lai F. A., Blayney L. M., Tan Y. P., Marty A. (2000): Presynaptic calcium stores underlie large-amplitude miniature IPSCs and spontaneous calcium transients. Nat. Neurosci. 3, 1256-1265 http://dx.doi.org/10.1038/81781

Markwell M. A. K., Haas S. M., Bieber L. L., Tolbert N. E. (1978): Modification of the Lowry procedure to simplify protein determination in membrane and lipoprotein samples. Anal. Biochem. 87, 206-210 http://dx.doi.org/10.1016/0003-2697(78)90586-9

Martin T. F. (2000): Racing lipid rafts for synaptic-vesicle formation. Nat. Cell. Biol. 2, E9-E11 http://dx.doi.org/10.1038/71392

Mauch D. H., Nagler K., Schumacher S., Goritz C., Muller E. C., Otto A., Pfrieger F. W. (2001): CNS synaptogenesis promoted by glia-derived cholesterol. Science 294, 1354-1357 http://dx.doi.org/10.1126/science.294.5545.1354

McNeil S. E. (2011): Characterization of nanoparticles intended for drug delivery. In: Methods in Molecular Biology 697 (Eds.: S. E. McNeil) p. 269, Humana Press., New Yourk

Merkus H. G. (2009): Particle size measurements. fundamentals, practice, quality. In: Particle Ttechnology Sseries. 13 (Eds. H. G. Merkus) p. 536, Springer science + Business Media B.V

Mutch S. A., Kensel-Hammes P., Gadd J. C., Fujimoto B. S., Allen R. W., Schiro P. G., Lorenz R. M., Kuyper C. L., Kuo J. S.,Bajjalieh S. M., Chiu D. T. (2011): Protein quantification at the single vesicle level reveals that a subset of synaptic vesicle proteins are trafficked with high precision. J. Neurosci. 31, 1461-1470 http://dx.doi.org/10.1523/JNEUROSCI.3805-10.2011

Neef A., Khimich D., Pirih P., Riedel D., Wolf F., Moser T. (2007): Probing the mechanism of exocytosis at the hair cell ribbon synapse. J. Neurosci. 27, 12933-12944 http://dx.doi.org/10.1523/JNEUROSCI.1996-07.2007

Oertner T. G., Sabatini B. L., Nimchinsky E. A., Svoboda K. (2002): Facilitation at single synapses probed with optical quantal analysis. Nat. Neurosci. 5, 657-664
Pickett J. A., Edwardson J. M. (2006): Compound exocytosis: mechanisms and functional significance. Traffic 7, 109-116 http://dx.doi.org/10.1111/j.1600-0854.2005.00372.x

Pieribone V. A., Shupliakov O., Brodin L., Hilfiker-Rothenfluh S., Czernik A. J., Greengard P. (1995): Distinct pools of synaptic vesicles in neurotransmitter release. Nature 375, 493-497 http://dx.doi.org/10.1038/375493a0

Pike L. J., Miller J. M. (1998): Cholesterol depletion delocalizes phosphatidylinositol bisphosphate and inhibits hormonestimulated phosphatidylinositol turnover. J. Biol. Chem. 273, 22298-22304 http://dx.doi.org/10.1074/jbc.273.35.22298

Portzehl H., Caldwell P. C., Ruegy J. C. (1964): The dependence of contraction and relaxation of muscle fibers from the crab maia squinado on the internal concentration of free calcium ions. Biochim. Biophys. Acta. 79, 581-591

Rosa P., Fratangeli A. (2010): Cholesterol and synaptic vesicle exocytosis. Commun. Integr. Biol. 3, 352-353 http://dx.doi.org/10.4161/cib.3.4.11831

Satzler K., Sohl L. F., Bollmann J. H., Borst J. G., Frotscher M., Sakmann B., Lubke J. H. (2002): Three-dimensional reconstruction of a calyx of Held and its postsynaptic principal neuron in the medial nucleus of the trapezoid body. J. Neurosci. 22, 10567-10579

Schikorski T., Stevens C. F. (2001): Morphological correlates of functionally defined synaptic vesicle populations. Nat. Neurosci. 4, 391-395 http://dx.doi.org/10.1038/86042

Shupliakov O. (2009): The synaptic vesicle cluster:a source of endocytic proteins during neurotransmitter release. Neuroscience 158, 204-210 http://dx.doi.org/10.1016/j.neuroscience.2008.03.035

Sudhof T. C. (2004): The synaptic vesicle cycle. Annu. Rev. Neurosci. 2, 7509-7547

Sudhof T. C., Rizo J. (2011): Ssynaptic vesicle exocytosis. Cold Spring Harb. Perspect. Biol. 3, a0056373

Takamori S., Holt M., Stenius K., Lemke E. A., Gronborg M., Riedel D., Urlaub H., Schenck S., Brugger B., Ringler P. et al., Muller S. A., Rammner B., Grater F., Hub J. S., De Groot B. L., Mieskes G., Moriyama Y., Klingauf J., Grubmuller H., Heuser J., Wieland F., Jahn R. (2006): Molecular anatomy of a trafficking organelle. Cell 127, 831-846 http://dx.doi.org/10.1016/j.cell.2006.10.030

Tarasenko A. S., Sivko R. V., Krisanova N. V., Himmelreich N. H., Borisova T. A. (2010): Cholesterol depletion from the plasma membrane impairs proton and glutamate storage in synaptic vesicles of nerve terminals. J. Mol. Neurosci. 41, 358-367 http://dx.doi.org/10.1007/s12031-010-9351-z

Taschenberger H., Leao R. M., Rowland K. C., Spirou G. A., von Gersdorff H. (2002): Optimizing synaptic architecture and efficiency for high-frequency transmission. Neuron 36, $1127-1143$ http://dx.doi.org/10.1016/S0896-6273(02)01137-6

Thiele C., Hannah M. J., Fahrenholz F., Huttner W. B. (2000): Cholesterol binds to synaptophysin and is required for biogenesis of synaptic vesicles. Nat. Cell Biol. 2, 42-49 http://dx.doi.org/10.1038/71366 
Tong G., Jahr C. E. (1994): Multivesicular release from excitatory synapses of cultured hippocampal neurons. Neuron 12, 51-59 http://dx.doi.org/10.1016/0896-6273(94)90151-1

Trikash I., Humeniuk V. P., Hromov L. O., Syrovats'ka L. P. (2003): Modulating effect of the antiseizure drugs on $\mathrm{Ca} 2+$-dependent membrane fusion in cell-free model of neurosecretion. Ukr. Biokhim. Zh. 75, 81-86

Trikash I., Gumenyuk V. P., Chernyshov V. I. (2004): The fusion of isolated synaptic vesicles as a model of final step of exocytosis. Neurophysiology 36, 238-246

Trikash I., Kolchinska L. (2006): Fusion of synaptic vesicles and plasma membrane in the presense of synaptosomal soluble proteins. Neurochem. Int. 49, 270-275 http://dx.doi.org/10.1016/j.neuint.2006.01.014

Trikash I. O., Volynets G. P., Remenyak O. V., Gorchev V. F. (2008): Dockingfusion of synaptic vesicles in cell-free model system of exocytosis. Neurochem. Int. 53, 401-407 http://dx.doi.org/10.1016/j.neuint.2008.09.010

Trikash I., Gumenyuk V., Lishko V. (2010): The fusion of synaptic vesicle membranes studied by lipid mixing: The R18 fluorescence assay validity. Chem. Phys. Lipids 163, 778-786 http://dx.doi.org/10.1016/j.chemphyslip.2010.09.003

Verhage M., Sorensen J. B. (2008): Vesicle docking in regulated exocytosis. Traffic 9, 1414-1424 http://dx.doi.org/10.1111/j.1600-0854.2008.00759.x

Wadel K., Neher E., Sakaba T. (2007): The coupling between synaptic vesicles and $\mathrm{Ca} 2+$ channels determines fast neurotransmitter release. Neuron 53, 563-575

http://dx.doi.org/10.1016/j.neuron.2007.01.021

Wadiche J. I., Jahr C. E. (2001): Multivesicular release at climbing fiber Purkinje cell synapses. Neuron 32, 301-313 http://dx.doi.org/10.1016/S0896-6273(01)00488-3

White H. S., Smith M. D., Wilcox K. S. (2007): Mechanisms of action of antiepileptic drugs. Int. Rev. Neurobiol. 81, 85-110 http://dx.doi.org/10.1016/S0074-7742(06)81006-8

Zamir O., Charlton M. P. (2006): Cholesterol and synaptic transmitter release at crayfish neuromuscular junctions. J. Physiol. 571, 83-99 http://dx.doi.org/10.1113/jphysiol.2005.098319

Zhang J., Xue R., Ong W. Y., Chen P. (2009): Roles of cholesterol in vesicle fusion and motion. Biophys. J. 97, 1371-1380 http://dx.doi.org/10.1016/j.bpj.2009.06.025

Zlatkis A., Zak B., Boyle A. J. (1953): A new method for the direct determination of serum cholesterol. J. Lab. Clin. Med. 41, 486-492

Received: July 19, 2012

Final version accepted: February 18, 2013 